MONIKA SZPICZAKOWSKA

Uniwersytet Jagielloński, Kraków

\title{
RZECZOWNIKI Z PRZYROSTKIEM -OTA W PANU TADEUSZU ADAMA MICKIEWICZA (ANALIZA SŁOWNIKOWA)
}

Niniejszy artykuł poświęcony jest opisowi odprzymiotnikowych rzeczowników z przyrostkiem -ota, występujących w tekście Mickiewiczowskiej epopei. Mimo niewielkiej, bo liczącej zaledwie pięć przykładów reprezentacji, rzeczowniki te stanowią interesujący materiał badawczy. $Z$ jednej strony bowiem odzwierciedlają tendencje rozwojowe charakterystyczne dla XIX-wiecznej polszczyzny ogólnej oraz regionalnej, północnokresowej. Z drugiej zaś ukazują niektóre właściwości idiolektu Mickiewicza i sposoby ich wykorzystania w utworze poetyckim.

Odprzymiotnikowe rzeczowniki z przyrostkiem -ota, jak wiadomo, należą do kategorii nazw abstrakcyjnych cech (NE), analogicznie jednak do innych derywatów z tej kategorii, często ulegają konkretyzacji, stając się nazwami nosicieli cech. Por. Dziwi mnie jego głupota 'to, że jest głupi', ale Takie zachowanie to głupota 'głupia rzecz'. Współcześnie stanowią typ nieregularny i nieproduktywny, o liczebności mniejszej niż 20 derywatów (GWJP: 417). Jak pokazują badania Krystyny Kleszczowej (1998: 72), również w przeszłości osiągają podobną liczebność. Autorka wynotowała ich bowiem z tekstów staropolskich 16. Jej zdaniem, wykazują one jednak znaczną żywotność, czego dowodem jest fakt, że ze wspomnianych 16 derywatów aż 5 dotrwało do naszych czasów. Są wśród nich dwa zachowane bez żadnych zmian (prostota, ślepota), dwa o zawężonym znaczeniu (ciemnota, suchoty) oraz jeden, który utracił motywację (cnota).

Interesujące uwagi na temat formacji z przyrostkiem -ota w średniowieczu i XVI wieku przynosi monografia Ewy Ostrowskiej, poświęcona ich zwycięskiemu konkurentowi, czyli rzeczownikom z przyrostkiem -ość. Według autorki sufiks -ota jest sufiksem starożytnym, już pod koniec średniowiecza ustępującym miejsca przyrostkowi -ość. Jego starożytność przejawia się w tym, że tworzy on derywaty wyłącznie od przymiotników rdzennych i niemotywowanych. Nie łączy się natomiast z podstawami rozwiniętymi, o obudowanych dwustronnie rdzeniach, których przybywało w miarę rozwoju języka. W przeciwieństwie do sufiksu -ota przyrostek -ość ma zdolność łączenia się z rozmaitymi podstawami przymiotnikowymi, stąd jego trwająca do połowy XVI wieku ekspansja na niemal wszystkie derywaty z kategorii NE (Ostrowska 1962: 328-330). O cofaniu się -ota pod naporem -ość, zdaniem E. Ostrowskiej (1962: 409), świadczy fakt, że w przypadku charakterystycz- 
nych dla staropolszczyzny dubletów rzeczowniki na -ość ustalały się w znaczeniu pierwotnym, rzeczowniki zaś na -ota obsługiwały różne znaczenia wtórne. Por. np. staropolską parę gołość - gołota, w której gołość oznacza 'bycie gołym', a gołota 'kogoś gołego, ubogiego'. Stabilizowanie się formacji z przyrostkiem -ota w funkcji wyrażania znaczeń wtórnych można zaobserwować także po XVI wieku, kiedy w polszczyźnie pojawiły się niespotykane wcześniej dublety, takie jak brzydkość - brzydota, ciasność - ciasnota, ciepłość - ciepłota, martwość - martwota, teskność - tęsknota, tępość - tępota. Ponieważ z dubletów tych do naszych czasów zachowały się jedynie rzeczowniki na -ota, za główną przyczynę ich żywotności E. Ostrowska uznaje możliwość przekazywania przez te rzeczowniki znaczeń wtórnych (1962: 417-420).

Analiza wydobytych z tekstu Pana Tadeusza rzeczowników z przyrostkiem -ota ma wykazać związek tych rzeczowników z XIX-wieczną polszczyzną ogólną lub jej regionalną, północnokresową odmianą. W tym celu zostaną one porównane $\mathrm{z}$ normą językową, zawartą w historycznych i współczesnych słownikach języka polskiego. Konfrontacja ze współczesną normą językową pozwala na wydzielenie wśród wspomnianych rzeczowników kilku grup:

1) rzeczowniki występujące w tym samym, co współcześnie, znaczeniu,

2) rzeczowniki występujące w odmiennym od współczesnego znaczeniu,

3) rzeczowniki, których współcześnie brak.

To samo znaczenie, co obecnie, ma w tekście poematu Mickiewicza tylko jeden rzeczownik z przyrostkiem -ota. Jest to rzeczownik cnota, dziś pozbawiony motywacji, w przeszłości zaś motywowany przez przymiotnik cny. Przymiotnik ten jako ostatni notuje SDor. i opatruje kwalifikatorem przestarzały. Będąc wyrazem motywującym dla rzeczownika cnota występował on w znaczeniu 'szlachetny, zacny, cnotliwy, uczciwy'. Znaczenie to słowniki zaliczają do jego podstawowych znaczeń, obok znaczenia 'czcigodny, dostojny, zaszczytny, sławny', por. SL, SWil., SW, SDor.

Rzeczownik cnota, jak podaje SDun., współcześnie wyraża trzy znaczenia: w liczbie mnogiej znaczenie 'pozytywna cecha charakteru; zaleta, przymiot, wartość wyższa', a bez liczby mnogiej znaczenia 'zespół wysokich wartości moralnych; prawość, zacność' oraz 'dziewictwo, dziewiczość'.

Podobnie definiuje ten rzeczownik SDor. z tym, że ostatnia definicja jest bardziej rozbudowana. Zgodnie z nią cnota to 'dziewiczość, niewinność, czystość'.

Oba podstawowe znaczenia rzeczownika cnota poświadczają także inne słowniki języka polskiego. U S.B. Lindego pojawia się on w znaczeniu 'ogół, zbiór własności, skłonności, uczynków zasługujących na zaletę', SWil. zaś i SW oprócz tego znaczenia notują również znaczenie 'przymiot dodatni, pewna zalecająca się własność, zaleta jakiej osoby, rzeczy, zwierzęcia'. Ponadto SW podaje ciekawą informację, że stosowanie wyrazu cnota w odniesieniu do rzeczy stanowi cechę staropolską. Powołuje się przy tym na opinię A. Mickiewicza, zgodnie z którą wyrazu tego używa się „,co do roślin i ciał nieorganicznych, tylko o ciałach czarodziejskich, lekarskich, kamieniach drogich (jako talizmanach) i lekarstwach; co do sprzętów, tylko o strzelbach i rynsztunku wojennym"1.

${ }^{1}$ Cyt. za SW. 
W tekście Mickiewiczowskiego poematu rzeczownik cnota występuje 5 razy. Trzykrotnie pojawia się w liczbie mnogiej, we właściwym dla tej formy znaczeniu 'dodatnie cechy, rysy charakteru; przymioty, zalety', por.:

Kiedy się człowiek uczy ważyć jak przystało

Drugich wiek, urodzenie, cnoty, obyczaje,

Wtedy i swoją ważność zarazem poznaje (I 397-399)²

Te wszystkie Tadeusza cnoty i zalety

Ściągnęły wzrok sąsiadki, uważnej kobiety (I 644-645)

Mąż dla cnót i patriotyzmu bardzo szanowany w Litwie (Objaśnienia, I 796)

Jedno użycie tego rzeczownika w liczbie pojedynczej wiąże się ze znaczeniem 'dziewiczość, niewinność, czystość', por.:

Pozostała mi tylko pamiątka jej cnoty,

Jej wdzięków i ten oto ślubny pierścień złoty. (X 278-279)

Wreszcie jeden raz rzeczownik cnota w liczbie mnogiej przekazuje charakterystyczne dla staropolszczyzny znaczenie dodatnich cech, przymiotów, zalet, ale nie osoby, lecz rzeczy, a konkretnie strzelby, por.:

Tu pokazywał strzelbę przedziwnej roboty,

Choć maleńką, i zaczął wyliczać jej cnoty. (IV 728-729)

Drugą grupę omawianych formacji na -ota stanowią dwa rzeczowniki występujące w tekście Pana Tadeusza w odmiennym od współczesnego znaczeniu.

Jednym z nich jest rzeczownik ciemnota, który dziś oznacza 'brak wykształcenia, obycia, zacofanie, tępotę'. Oprócz tego znaczenia SDun. podaje dla niego jeszcze dwa przenośne znaczenia, kwalifikowane jako potoczne: 'środowisko, grupa ludzi niewykształconych, zacofanych' oraz 'lekceważąco o osobie niewykształconej, zacofanej'.

Oba typowe dla dzisiejszej polszczyzny znaczenia rzeczownika ciemnota, czyli 'brak oświaty, zacofanie' oraz 'ludzie ciemni, nieoświeceni' pojawiają się także w SDor., który ponadto notuje jego wcześniejsze, dosłowne znaczenie 'ciemność, brak światła, jasności, mrok'. Znaczenie to ilustruje cytatami z utworów XVIII- i XIX-wiecznych pisarzy, w tym z IV części Dziadów A. Mickiewicza.

Wymienione przez SDor. jako trzecie dosłowne znaczenie wyrazu ciemnota inne historyczne słowniki języka polskiego umieszczają na pierwszym miejscu. SL ogranicza się wyłącznie do tego znaczenia, a na jego potwierdzenie przytacza dwa cytaty z Łukasza Górnickiego i Adama Naruszewicza. SWil. i SW podają dla rzeczownika ciemnota najpierw znaczenie 'brak światła, ciemność, mrok', w dalszej zaś kolejności znaczenie ‘brak oświecenia, oświaty’ z tym, że SW pierwsze z tych znaczeń opatruje kwalifikatorem mało używane.

2 Podane przykłady pochodzą z wydania Pana Tadeusza w opracowaniu Stanisława Pigonia (Mickiewicz 1994). 
Rzeczownik ciemnota pojawia się w tekście Pana Tadeusza tylko raz w dosłownym znaczeniu 'ciemność, mrok', por.:

... strug dalej upada do dołu;

Upada, lecz nie ginie, bo w rowu ciemnotę

Unosi na swych falach księżyca pozłotę; (VIII 597-599)

Podobne użycia tego rzeczownika można spotkać również w innych utworach A. Mickiewicza. Występują one np. w IV części Dziadów: Tysiąc ogniów północne rozpędza ciemnoty (922), w Sonetach Krymskich: Usypiam pod skrzydłami ciszy i ciemnoty (XII 9), w wierszu Do Doktora S. Każemy pękać górom, znidziem w ich ciemnote (27) czy w poemacie Giaur, w którym znajduje się wyrażenie ciemnota mogity (239) ${ }^{3}$. Jak podaje SJAM, poeta użył wyrazu ciemnota w znaczeniu 'brak światła, ciemność, mrok, noc' 12 razy, a w znaczeniu 'niewiedza' jedynie 5 razy.

Rzeczownik ciemnota oznaczający 'ciemność' prawdopodobnie już w XIX wieku stanowił archaizm. Świadczą o tym zawarte w słownikach przykłady jego użyć, których część pochodzi z tekstów XVI- i XVIII-wiecznych pisarzy. Natomiast XIX-wieczne użycia tego wyrazu przeważnie zostały zaczerpnięte z utworów A. Mickiewicza. Ponadto, o czym już wspominano, SW, gromadzący słownictwo XIX wieku, kwalifikuje znaczenie 'ciemność, mrok' omawianego rzeczownika jako mało używane. Za XIX-wieczny archaizm uznaje rzeczownik ciemnota w znaczeniu 'ciemność' także Zofia Kurzowa (1963: 132), która uważa, że jego zachowanie się na kresach północnych, w tym w języku A. Mickiewicza, podtrzymywane było przez wpływ ruski.

Drugim rzeczownikiem z przyrostkiem -ota występującym w tekście Pana Tadeusza w odmiennym od dzisiejszego znaczeniu jest rzeczownik hołota. Współcześnie SDun. podaje dla niego dwa znaczenia: 'pogardliwie o ludziach niewykształconych, niekulturalnych, zachowujących się w ordynarny sposób; motłoch, hałastra, męty, łobuzeria, tałatajstwo' oraz 'żartobliwie o hałasujących dzieciach, ptakach'. Oba te znaczenia po raz pierwszy pojawiają się dopiero w SDor., nie notuje ich ani SL, ani SWil, a SW łączy znaczenie "pospólstwo, tałatajstwo, hałastra zbieranina' ze znaczeniem 'ludzie biedni' w jedną definicję.

Wymienione jako drugie przez SDun. i SDor. znaczenie rzeczownika hołota, odnoszące się do małych dzieci i ptaków, poświadcza jeden z dwóch przykładów tego rzeczownika, występujących w tekście Mickiewiczowskiego poematu, por.:

A drugą ręką z czapki proso w trawę miota

Dla wróblów; spada z dachów krzykliwa hołota. (VI 595-596)

Warto dodać, że cytat ten umieszcza w haśle hołota nie tylko SDor. dla zilustrowania definicji ‘żartobliwie o małych dzieciach, zwierzętach', ale także SW w celu potwierdzenia znaczenia 'pospólstwo, tałatajstwo, hałastra, zbieranina', opatrując go kwalifikatorem przenośnie.

Starsze, odmienne od współczesnych znaczenia omawianego rzeczownika notują SL, SWil. i SW. Na pierwszym miejscu wymieniają znaczenie 'człowiek ubogi, hołysz, golec, biedak', które wzbogacone o element 'łobuz’ poświadcza także SDor., kwalifikując jako

${ }^{3}$ Przykłady wraz z lokalizacją cyt. za SJAM. 
potoczne. W dalszej kolejności podają znaczenie zbiorowe 'ludzie biedni, ubodzy, ubogi lud'. Oba te znaczenia mają swoje źródło w staropolskim wyrazie gołota, będącym określeniem człowieka nie posiadającego ziemi. Jak stwierdza E. Ostrowska (1962: 317), wyraz ten początkowo stanowił termin prawniczy, dobrze znany tekstom średniowiecznym, który z czasem przekształcił się $\mathrm{w}$ rzeczownik zbiorowy hołota, oznaczający ludzi ubogich, gorszych, skąd już było blisko do jego dzisiejszego, pejoratywnego znaczenia 'motłoch, hałastra, męty, łobuzeria, tałatajstwo'. Najprawdopodobniej zaczęło się ono kształtować w XIX wieku, na co wskazuje zamieszczona w SW definicja wyrazu holota, łącząca ze sobą dwa znaczenia: 'ludzie biedni' oraz 'pospólstwo, tałatajstwo, hałastra, zbieranina'.

Drugi przykład rzeczownika holota, występujący w tekście Pana Tadeusza nawiązuje do starszego znaczenia tego rzeczownika 'hołysz, golec, biedak', a nawet, jak zauważa S. Pigoń, do znaczenia staropolskiego wyrazu gołota 'szlachcic goły, ubogi' (Mickiewicz 1994: 312, przypis). W znaczeniu tym pojawia się jako określenie Maćka Dobrzyńskiego we fragmencie poematu zawierającym opis jego domostwa, por.:

Jak on nad Dobrzyńskimi, dom jego nad siołem

Panował, stojąc między karczmą i kościołem.

Widać rzadko zwiedzany, mieszka w nim hołota

Bo brama sterczy bez wrot, ogrody bez płota, (VI 427-430)

Z dwóch użyć rzeczownika holota znajdujących się w tekście Pana Tadeusza jedno zatem wykracza poza XIX-wieczną normę językową, dając początek nowemu znaczeniu, drugie zaś stanowi na jej tle wyraźny archaizm, wykorzystany przez poetę do celów stylistycznych.

Trzecią grupę wydobytych z tekstu poematu Mickiewicza formacji na -ota tworzą nie występujące we współczesnej polszczyźnie rzeczowniki pustota i szczodrota.

Rzeczownik pustota po raz ostatni odnotowany został w SDor., który opatruje go kwalifikatorem przestarzały. Do jego podstawowych znaczeń zalicza dwa znaczenia: 'skłonność do figlów, żartów, do postępowania lekkomyślnego; usposobienie lekkomyślne, wesołe; beztroska, trzpiotowatość, lekkomyślność' oraz 'beztroskie spędzanie czasu na zabawie, żartach, figlach; zabawa, dokazywanie, swawola, postępek lekkomyślny, beztroski; figiel, żart'. Oba te znaczenia poświadcza cytatami z tekstów literackich XIX i początku XX wieku, m. in. Adama Mickiewicza, Władysława Syrokomli, Adolfa Dygasińskiego, Marii Konopnickiej, Gabrieli Zapolskiej, Stefana Żeromskiego, Jana Parandowskiego.

Pozostałe słowniki języka polskiego podają dla rzeczownika pustota tylko jedno znaczenie. SL definiuje go jako 'swawola, lekkość, lekkomyślność, pusta myśl, fiu fiu w głowie, świszczypalstwo', podobną definicję tego rzeczownika przytacza SWil. 'pusta myśl, lekkość, lekkomyślność, postępek lekki, swawola, ale nie błąd', SW zaś w definicji wyrazu pustota łączy ze sobą dwa znaczenia: 'myśl pusta, swawola bezmyślna, lekkomyślność, trzpiotowatość, płochość' oraz 'postępek nacechowany pustotą, pusty żart, zbytki'.

Wymienione definicje rzeczownika pustota słowniki ilustrują cytatami zaczerpniętymi z utworów XVI- i XVIII-wiecznych pisarzy. Wypada jednak zauważyć, że tylko cytat Wlazł przez pustotę na drzewo, pochodzący z pism A. Naruszewicza ${ }^{4}$ poświadcza znacze-

${ }^{4}$ Cyt. za SL. 
nie 'lekkomyślność' tego rzeczownika. Natomiast inne cytaty, w szczególności z tekstów XVI-wiecznych, wskazują na jego staropolskie znaczenie 'rozpusta'. Należy dodać, że zgodnie z ustaleniami E. Ostrowskiej (1962: 414) w tekstach z XVI wieku można spotkać wyłącznie to znaczenie rzeczownika pustota. Podane przez słowniki znaczenie 'lekkomyślność, trzpiotowatość, płochość’ tego rzeczownika okazuje się więc znaczeniem późniejszym, prawdopodobnie XVIII-wiecznym.

Za jeszcze późniejsze, jak się zdaje XIX-wieczne, trzeba uznać jego drugie znaczenie 'beztroska zabawa, figiel, żart'. Znaczenia tego nie notuje ani SL, ani SWil., SW ogranicza się tylko do jego pewnych elementów, a jako odrębne znaczenie wymienia je dopiero SDor.

Do znaczenia 'figiel, żart' rzeczownika pustota odnosi się jedyny przykład tego rzeczownika zawarty w tekście Pana Tadeusza, por.:

Zabawiła nas cały wieczór ta pustota;

Zrobiła się nazajutrz z tego anegdota,

Że w sądy o mym piesku Wielki Łowczy wdał się;

I nawet wiem z pewnością, że sam Cesarz śmiał się. (II 653-656)

Drugim rzeczownikiem z przyrostkiem -ota, obcym dzisiejszej polszczyźnie jest rzeczownik szczodrota. Jego współczesny odpowiednik stanowi wyraz szczodrość, który SDun. definiuje jako 'hojne i chętne dawanie, obdarowywanie kogoś; bycie szczodrym'.

Słowniki historyczne z XX wieku uznają rzeczownik szczodrota za archaizm. SDor. widzi w nim wyraz dawny, a SW - staropolski.

Najbardziej rozbudowaną definicję tego rzeczownika podaje SDor. Zgodnie z nią szczodrota to 'hojność w rozdawaniu czego; szczodrość, szczodrobliwość, rzecz udzielona hojnie, szczodrze; obfitość czego'. Inne słowniki, jak SL czy SWil., ograniczają się do znaczenia 'hojna dobroczynność' tego wyrazu lub, jak SW, poprzestają na wyliczeniu jego synonimów 't. s., co szczodrobliwość, szczodrość'.

Rzeczownik szczodrota pojawia się w tekście Pana Tadeusza tylko raz w znaczeniu zbliżonym do podanego przez SDor. znaczenia 'obfitość czego'. Poeta użył go w stylizowanej na język staropolski przemowie Sędziego, zawierającej naukę o grzeczności, por.:

Zaś godna jest Waszmościów uwagi osobnej

Grzeczność, która powinna młodź dla ptci nadobnej;

Zwtaszcza gdy zacność domu, fortuny szczodroty

Objaśniaja wrodzone wdzięki i przymioty. (I 402-405)

Warto dodać, że znaczenie rzeczownika szczodrota znajdującego się w przytoczonym fragmencie poematu SJAM określa jako przenośne. Podobnego zdania jest S. Pigoń, który w wyrażeniu fortuny szczodroty dopatruje się peryfrazy - figury stylistycznej typowej dla staropolskiej retoryki i przypisuje mu znaczenie ‘bogactwo' (Mickiewicz 1994: 37, przypis). Obie te uwagi wyraźnie wskazują, że A. Mickiewicz posłużył się archaicznym wyrazem szczodrota świadomie, w celu stylizacji na język staropolski.

Analiza odprzymiotnikowych rzeczowników z przyrostkiem -ota występujących w tekście Mickiewiczowskiej epopei pozwala stwierdzić, że po części realizują one tendencje języka ogólnopolskiego, po części zaś nawiązują do zjawisk właściwych polszczyźnie, 
regionalnej, północnokresowej. Związek z językiem ogólnopolskim przejawia się głównie w niewielkiej ilości tych rzeczowników, które od XVI wieku podlegały ograniczeniu na rzecz innych formacji, zwłaszcza z sufiksem -ość. Natomiast cechą łączącą analizowane wyrazy z polszczyzną północnokresową jest archaiczność tych wyrazów lub ich niektórych znaczeń. Wśród zgromadzonych rzeczowników z przyrostkiem -ota zdecydowane archaizmy stanowią rzeczowniki ciemnota w znaczeniu 'ciemność' i szczodrota. W XIX wieku archaizmem nie jest natomiast rzeczownik pustota, chociaż współcześnie uważa się go za wyraz przestarzały. Archaicznego charakteru w zasadzie nie mają także wyrazy cnota i hołota. Za charakterystyczne dla dawnej polszczyzny trzeba jednak uznać niektóre ich użycia, jak użycie rzeczownika cnota w funkcji oznaczania cech dodatnich, przymiotów, zalet strzelby czy rzeczownika hołota jako określenia szlachcica gołego, ubogiego. Większość archaicznych rzeczowników z przyrostkiem -ota, zawartych w tekście Pana Tadeusza odznacza się nacechowaniem stylistycznym. Zostały one bowiem świadomie użyte przez poetę w celu stylizacji na język staropolski. Nacechowania takiego nie wykazuje rzeczownik ciemnota w znaczeniu 'ciemność', który utrzymywał się dłużej na kresach północnych pod wpływem ruskim. Wprawdzie pozostałe archaizmy na -ota również mogły występować w ówczesnej polszczyźnie północnokresowej, wydaje się jednak, że ich głównym źródłem była tradycja literacka. W związku z tym za częściowo słuszne należałoby uznać poglądy dawnych badaczy, którzy obecność archaizmów w języku autora Pana Tadeusza łączyli z wpływami wcześniejszych poetów oraz słownika S.B. Lindego jako stałych lektur A. Mickiewicza. Występujące w tekście Mickiewiczowskiego poematu archaiczne rzeczowniki z przyrostkiem -ota ze względu na funkcję i pochodzenie można więc podzielić na dwie grupy: archaizmy stylistyczne, mające swoje źródło w tradycji literackiej (szczodrota, częściowo cnota i hołota) oraz archaizmy systemowe, przynależne do systemu idiolektalnego poety (ciemnota w znaczeniu 'ciemność').

\section{Skróty}

cyt. - cytowane

$\mathrm{NE}$ - nomina essendi

\section{Źródło}

Mickiewicz A., 1994, Pan Tadeusz, opr. S. Pigoń, BN I/83, wyd. 10, Wrocław-Warszawa-Kraków.

\section{Bibliografia}

GWJP - Gramatyka współczesnego języka polskiego. Morfologia, red. R. Grzegorczykowa, R. Laskowski, H. Wróbel, Warszawa 1998.

Kleszczowa K., 1998, Staropolskie kategorie słowotwórcze i ich perspektywiczna ewolucja. Rzeczowniki, Katowice.

Kurzowa Z., 1963, Język filomatów i filaretów. Słowotwórstwo i słownictwo, Wrocław-WarszawaKraków. 
Mróz-Ostrowska E., 1962, Rzeczowniki z przyrostkiem -ość w języku XVI w., w: Odrodzenie w Polsce, t. 3, cz. 2, Warszawa, s. 303-503.

SDor. - Słownik języka polskiego, red. W. Doroszewski, t. I-XI, Warszawa 1958-1968.

SDun. - Słownik współczesnego języka polskiego, red. B. Dunaj, Warszawa 1996.

SJAM - Stownik języka Adama Mickiewicza, red. K. Górski i S. Hrabec, t. I-XI, Wrocław-Warszawa-Kraków 1962-1983.

SL - S.B. Linde, Słownik języka polskiego, t. I-VI, wyd. 2, Lwów 1854-1860.

SW - J. Karłowicz, A. Kryński, W. Niedźwiedzki, Słownik języka polskiego, t. I-VIII, Warszawa 1900-1927 (tzw. warszawski).

SWil. - Słownik języka polskiego wypracowany przez A. Zdanowicza, M. Bohusza-Szyszke, J. Filipowicza, t. I-II, Wilno 1861 (tzw. wileński).

\section{MONIKA SZPICZAKOWSKA}

\section{Nouns with the -ota suffix in Adam Mickiewicz's Pan Tadeusz (lexical analysis)}

\section{Summary}

The article is dedicated to a lexical analysis of adjectival nouns with the -ota suffix in Adam Mickiewicz's Pan Tadeusz. Out of five nouns, viewed against the $19^{\text {th }}$ century language norm, four are definitely archaisms. These are the words: ciemnota meaning <ciemność - darkness>, szczodrota (generosity) and some uses of the words cnota (virtue) and holota (the poor and badly educated). On top of the noun ciemnota meaning <ciemność - darkness $>$ which is a typical Easter Borderlands archaism, they should be traced back to the literary tradition. This is corroborated by the fact that the poet used them in an informed way to make the text sound like Old Polish. Therefore, with respect to the function and the archaic origin, the nouns with the -ota suffix in the text of "Pan Tadeusz" can be divided into two groups: stylistic archaisms which come from the literary tradition (szczodrota, partly cnota and hotota) plus systemic archaisms which belong to Mickiewicz's idiolectal system (ciemnota meaning <ciemność - darkness>).

Keywords: adjectival nouns with the -ota suffix, "Pan Tadeusz", Old Polish style, archaisms. 